\section{UMP1-021＼cjkstart前立腺藻細胞株における低酸秦誘 導遗伝子の発現解析}

\begin{abstract}
大分大学医学部腫瘦病態制御講座泌尿器科
山崎 六志, 野村 威雄, 佐藤 文憲, 秦 聡孝,

三股 浩光

【目的】多くの癌において腫瘍内が低酸素状態になること が報告されており、またそれが治療（化学療法、放射線 療法）や apoptosisへの抵抗性に関与していることが示 唆されている。今回我々は低酸素下における前立腺癌細 胞の遺伝子発現について検討を行った。

【方法】前立腺癌細胞株 $(\mathrm{LNCaP})$ を normoxia $\left(21 \% \mathrm{O}_{2}\right)$ 押 よび severe hypoxia $\left(0.45 \% \mathrm{O}_{2}\right)$ にて培養し、DNA マイ クロアレイにて遺伝子発現解析を行った。また、前立腺 癌細胞株 (LNCaP、PC-3) を normoxia $\left(21 \% \mathrm{O}_{2}\right) 、$ hypoxia $\left(5 \% \mathrm{O}_{2}\right)$ および severe hypoxia $\left(0.45 \% \mathrm{O}_{2}\right)$ にて培 盖し、real time RT-PCR を用いて解析を行った。

【成績】DNA マイクロアレイ解析において、低酸素刺激 にて c-fos、c-jun、VEGF、metallothionein 等の発現六進 がみられた。 real time RT-PCR でも同様の結果が得られ た。

【結論】低酸素下ではc-fos、c-junを介して metallothionein 等の発現が誘導されることが示唆された。ま た、metallothionein は抗癌剂耐性に関与する遺伝子であ り、さらに詳しく発現機序を解析する予定である。
\end{abstract}

\section{UMP1-022 ヒト前立腺癌細胞株におけるケモ カイン受容体の発現に及ぼすアン ドロゲンの影響について}

\footnotetext{
富山医科薬科大学医学部泌涾器科"), 富山医科薬科大学 和漢薬研究所病態制御部門病態生化学分野 ${ }^{2}$, 近畿大学 医学部細菌学教室 ${ }^{3}$

明石 拓也"), 永川 修1), 小泉 桂一 ${ }^{2)}$, 中山 隆志 ${ }^{3)}$, 中村 エリア亦静 ${ }^{2}$, 小林 光夫 ${ }^{22}$, 稗島 州雄 ${ }^{32}$,

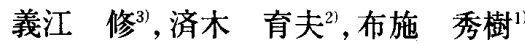

【目的】ケモカインはもともと白血球の遊走因子として同定 されたサイトカインより低分子量の一群の生理活性タンパ クであり最近の研究で前立腺癌の骨転移にもケモカイン/ケ モカイン受容体の pathway の関与が示唆されている。すで に我々はアンドロゲン受容体 $(\mathrm{AR})$ が発現していないヒト前 立腺癌紐胞株 DU-145に AR を過剩発現させることにより、 CXCR4の mRNA レベルでの発現が立進することを報告し てきた。今回我々は、ヒト前立腺癌細胞株の CXCR4 の発現 元進に及ほすアンドロゲンの影響について検討した。】方 法】ARを恒常的に発現する細胞株 LNCap のデヒドロテス トステロン（DHT）刺激による mRNA レベルでの CXCR4 発現変化を RT-PCR 法により確認した。結果】LNCaP の增 殖至適 DHT 濃度下に挍いて、CXCR4 の mRNA 発現は元進 していた。今後この発現の差を real-time PCR 法でさらに詳 細に解析し、CXCR4 発現六進を誘導するDHT の影響をシ グナル伝達系の観点から解析を進めてゆく予定である。
}

\section{UMP1-023 前立腺癌における survivin 蛋白の 発現、内分泌療法の治韵効果と予 後との関連について}

\author{
島根大学医学部泌尿器科 \\ 岸 浩史, 菊野 伸之, 足立 浩幸, 米田 達明, \\ 滋野 和志, 椎名 浩昭, 井川 幹夫
}

【目的】Survivinはアポトーシスを抑制する蛋白で、各種癌組織にお いてその悪性度や予後との関連性が示唆されている。前立腺癌組織 における survivin 蛋白の発現と内分泌療法の治療効果や予後との 関連を免疫組織学的に語価した。【方法】内分泌䖍法を施行した前立 腺癌 42 例を対象とし、治療前の針生検組織を用い免疫組織学的に survivin 蛋白の発現を観察し、臨床病理学的検討項目との関係につ いて検討した。成績]Survivin 蛋白の発現は、42 例中 28 例 $(66.7 \%)$ で認められた。臨床病期、Gleason score、、治療前PSA 值に関しては、 Survivin 陽性群と陰性群の間でいずれも有意差はなかった。PSA 再発症例 20 例を対象とした検討では、 survivin 陽性群 $(n=13)$ お よび陰性群 $(\mathrm{n}=7)$ での PSA 低下率はそれぞれ 93.7\%、99.0\%、PSA nadir は $11.5 \mathrm{ng} / \mathrm{ml} 、 1.3 \mathrm{ng} / \mathrm{ml} 、 \mathrm{PSA}$ 再発までの平均期間は 114.2 weeks、171.9weeksであった(いずれも有意差なし)。また、3年累 皘非再発率はそれぞれ $31 \% 、 57 \% 、 5$ 年累皘非再発率は $8 \% 、 14 \%$ $(\mathrm{p}=0.14)$ 、さらに、 5 年生存率は $58 \% 、 83 \%$ であった $(\mathrm{p}=0.11)$ 。 【結論】前立腺癌組織において、42 例中 28 例 $(66.7 \%) に$ r survivin 蛋白の発現が浔められた。Survivin 陽性群に打いて累皘非再発率や 生存率が低い㑯向が認められたことより、survivin 蛋白の発現が前 立腺癌の予後と関連している可能性が示唆された。

\section{UMP1-024 マウス前立腺におけるエストロゲ ン誘発性增殖性病変の誘導メカニ ズム}

\footnotetext{
三重大学医学部泌尿器科

金井 優博, 石井 健一郎, 神田 英輝,

フランコ オマール,有馬 公伸, 杉村 芳樹

【日的】マウスへエストロゲンを投与した場合、前立腺上皮 の增殖性病変 Squamous Metaplasia (SQM) が認められる。 この時、エストロゲン受容体 $\alpha(E R \alpha)$ の発現が必須である。 近年、in vitro の実験系において、エストロゲンが $\mathrm{ER \alpha}$ を介 して Transforming growth factor alpha (TGF $\alpha$ )の発現を誘 導することが報告された。そこで、我々はマウス前立腺上皮 細胞における TGF $\alpha$ の発現誘導と SQM との関係を検討し た。【方法】ER $\alpha, T G F \alpha$ の発現はウェスタンブロッティング 法により定量測定した。SQM は、マウス前立腺無血清器官 培盖法を用い, CK10 およびCK14 の発現を免疫組織学的に 検討、評価した。【結果】マウス前立腺上皮由来紐胞株におけ る ER $\alpha, \mathrm{TGF} \alpha$ の発現はエストロゲンの濃度依存的に上昇 した。無血清器官培養法において、TGF $\alpha$ はエストロゲンと 同様にCK10，CK14 陽性の SQM を誘導した。この時、エス トロゲンが $\mathrm{ER} \alpha, \mathrm{TGF} \alpha$ の発現を、 $\mathrm{TGF} \alpha$ が $\mathrm{ER} \alpha$ の発現を 誘導していることを免疫組織学的に確認した【結論】マウ ス前立腺における SQM の誘導が、エストロゲンによる TGF $\alpha$ の発現誘導を介して引き起こされていること、さら に TGF $\alpha$ 自体に SQM 誘導能があることを明らかとした。
} 